\title{
Object manipulation, tool use, and the social context in human and non-human primates
}

Jacques Vauclair and James. R Anderson

\section{(2) OpenEdition}

1 Journals

Electronic version

URL: https://journals.openedition.org/tc/556

DOI: $10.4000 /$ tc.556

ISSN: 1952-420X

Publisher

Éditions de l'EHESS

Printed version

Date of publication: 1 November 1995

ISSN: 0248-6016

\section{Electronic reference}

Jacques Vauclair and James. R Anderson, "Object manipulation, tool use, and the social context in human and non-human primates", Techniques \& Culture [Online], 23-24 | 1995, Online since 07

December 2005, connection on 29 September 2022. URL: http://journals.openedition.org/tc/556 ; DOI: https://doi.org/10.4000/tc.556

This text was automatically generated on 29 September 2022.

All rights reserved 
Object manipulation, tool use, and the social context in human and non-human primates

Jacques Vauclair and James. R Anderson 